\title{
Construction and Innovation of "TCPP" Teaching Mode of International Settlement from the Perspective of Applied Talent Training Objectives
}

\author{
Min Xu (Corresponding Author) \\ School of International Economics and Trade, Anhui University of Finance \& Economics, Bengbu, Anhui, China \\ Email: 120081584@aufe.edu.cn
}

\section{Hong Chen}

School of International Economics and Trade, Anhui University of Finance \& Economics, Bengbu, Anhui, China
Article History

Received: 11 October, 2021

Revised: 28 November, 2021

Accepted: 21 December, 2021

Published: 27 December, 2021

Copyright (C) 2021 ARPG \&

Author

This work is licensed under the

Creative Commons Attribution International

(c) (1) CC BY: Creative

Commons Attribution License 4.0

\begin{abstract}
Under the background of the new era, it is particularly urgent to reform the teaching content and teaching mode of international settlement in order to meet the needs of talents and cultivate new applied talents of international settlement. Firstly, this paper analyzes the market demand for applied talents in international settlement, defines the teaching objectives of applied talents training in international settlement, and explores the main problems existing in the existing teaching mode of international settlement. Secondly, on this basis, this paper constructs the "TCPP" teaching mode of international settlement, and finally puts forward the problems that should be paid attention to in the application of "TCPP" so as to effectively improve the teaching effect, meet the needs of the actual business, achieve the training goal of applied talents in colleges and universities, meet the social demand for talents and achieve win-win results for all parties.
\end{abstract}

Keywords: International settlement; Applied talents; TCPP teaching mode; Curriculum innovation.

\section{Introduction}

International settlement is a professional core course of international trade, finance and other majors. It is a business and skill that students must master in foreign trade and foreign-related finance in the future. Its professional, foreign-related, practical and comprehensive characteristics are very prominent. Nowadays, with the accelerating process of global economic integration, trade, investment and related international financial activities are becoming increasingly active and expanding in breadth and depth, resulting in a sharp increase in the volume of international settlement business and an increasing demand for international settlement talents. Enterprises pay more and more attention to international settlement talents, which not only require them to have solid theoretical knowledge and good English ability, but also have strong business ability and innovation ability. At present, the course of international settlement is mainly based on the traditional teaching mode of "Teacher centered", and students are only in the position of passive acceptance. The learning and understanding of knowledge mainly comes from teachers' classroom teaching, which is not conducive to students' mastery of professional knowledge and the cultivation of relevant professional skills. These problems lead to students' failure to meet the employment requirements of enterprises and a serious gap between talent supply and demand. And they do not comply with the training objectives of colleges and universities. In view of this, the research on the construction and innovation of "TCPP" teaching mode of international settlement course under the training goal of applied talents has important theoretical significance and practical value for promoting the improvement of employability of international settlement talents and the teaching practice reform of international settlement course in colleges and universities.

In view of the defects of the traditional teaching mode, many teachers constantly summarize and innovate in teaching practice, and explore the reform of building a new teaching mode of "student-centered". The research on this issue mostly focuses on the following three aspects: first, the research on the training objectives and curriculum reform of international settlement. Wang Xiaodong (2013) believed that the innovative training mode of product business of commercial banks should be introduced to build the laboratory of international settlement. Wang Na (2019) made a preliminary exploration on the teaching reform of international settlement course mainly through talent demand research, teaching design reform and improving software and hardware facilities based on the educational goal of application-oriented talent training. Third, the research on the teaching method of international settlement. Xiao Jing (2020) carried out curriculum reform and practice under the guidance of OBE concept, explored the establishment method of clear learning objectives, reverse designed teaching content guided by "quality education + innovation ability", more scientific curriculum evaluation system, etc., and put forward some suggestions on supporting measures that colleges and Universities should give teachers in supporting curriculum 
teaching reform. Meng Liang (2021) can realize the reform of "PBL + semi flipped classroom" teaching mode guided by application problems, dominated by students' self-learning, supplemented by teachers' guidance and professors in the teaching of professional courses of economic management. This teaching mode has played a positive role in stimulating students' interest in learning and improving the teaching effect of professional courses.

Generally speaking, although these new teaching modes of international settlement have different forms, their essence is to explore the teaching concept of "student-centered", enhance students' learning initiative and improve students' practical ability and innovation ability. However, these new teaching models still have some problems: first, they fail to design a suitable teaching model of international settlement from the perspective of the specific talent needs of enterprises. The demand for talents in international settlement is mainly foreign trade enterprises and banks. These two types of units have similarities and differences in talent demand. Whether teachers adopt passive or active teaching mode, they should start according to the characteristics of talent demand of these two types of units, so as to cultivate the international settlement talents that enterprises really need. Second, the proposal of the existing new teaching mode of international settlement focuses on one aspect, such as emphasizing practical teaching links, which is not comprehensive, especially the comprehensive construction and innovation of the teaching mode of international settlement is not specific and profound. In view of this, this paper selects the construction and innovation of the "TCPP" teaching mode of the international settlement course under the training goal of applied talents as the research object, analyzes and studies the relevant problems, and tries to put forward operable suggestions for the innovation and reform of the training mode of applied talents.

\section{Material and Method}

With the in-depth development of economic globalization and financial market integration, international cultural, economic and political exchanges are becoming more and more frequent. The application of electronic technology has expanded the time and space of international economic and trade business and rapidly expanded the scale of foreign economy. The change of international trade situation and the emergence of cross-border e-commerce have promoted the rapid development of international settlement. The traditional international settlement methods can no longer adapt to the new trend of international trade development. For example, the three traditional international settlement methods of L / C, t / T and D / P have complex settlement procedures, high economic cost and long cycle, The reasons emerge in an endless stream of Internet plus electricity providers, such as the need for direct dealings between the buyers and sellers, etc., which can no longer meet the urgent demand of cross-border ebusiness for the convenience of online payment under the background of "Internet + ". With the help of Paypal and other three party payment platforms, cross-border payment has become a new bright spot in the international settlement mode. With the rapid development of international settlement, the demand for new international settlement talents continues to rise, especially for technical application talents who can be directly competent for international settlement related posts in trading companies, large production enterprises with import and export business, cross-border e-commerce and other enterprises. In order to meet the requirements of the new international economic situation, international settlement has become a professional backbone course for the majors of international trade, international business and international finance in Colleges and universities. The teaching of international settlement is mainly based on the basic theories and laws of international settlement, conforms to the changes and reforms of the international payment system and the application of high-tech information technology in international settlement, and systematically introduces the principles, international practices, conditions, methods and means of international settlement business operation and the latest development trends, It also provides a large number of original English materials, examples, business documents and business procedure diagrams when expounding international banking business, so as to make each business intuitive and operable.

\subsection{Demand for Applied Talents in International Settlement and Teaching Objectives}

Under the background of economic globalization and the deepening of China's reform and opening up, China's foreign economic and trade activities and other exchanges continue to expand in depth and breadth, resulting in an increasing demand for international settlement business and a surge in the demand for international settlement talents.

The demand for international settlement talents is mainly concentrated in foreign trade enterprises, banks and other departments. The main characteristics of foreign trade enterprises' demand for international settlement talents: first, they should have solid theoretical knowledge, understand the general laws of social and economic activities and national macroeconomic policies from a theoretical perspective, skillfully master the production, opening and review of bills, documents and letters of credit commonly used in practical business, and be familiar with the processes of various settlement methods, have the awareness of financing and avoiding settlement risk; Secondly, be familiar with business operation process, have strong practical ability, and can quickly adapt to enterprise management and market competition environment; Thirdly, have high professional quality and sense of social responsibility, be practical, hardworking and responsible. The main characteristics of banks' demand for international settlement talents: as commercial banks have vigorously expanded intermediary business in recent years and international settlement is one of the important businesses and quite complex, banks have a great demand for international settlement talents. First, as employees of international settlement departments, they need to master the basic theoretical knowledge of international settlement, which is conducive to the audit link of banking work and identifying risks in advance; Second, in the process of reviewing documents, since the documents used by the three main settlement methods in international settlement business are written in English, employees are required to have good English skills; Third, the trade financing involved in different ways of international settlement has been valued 
by commercial banks. Students should master the ability of financing business; Fourth, from the perspective of the development of domestic commercial banks, all commercial banks are paying attention to the expansion of international settlement business, and there is a certain homogeneity in the international settlement products and services in the current market. Therefore, the bank hopes that the school can cultivate students' innovation ability while teaching basic theories. It should be emphasized that the professional ethics of honesty and trustworthiness is the premise and foundation for international settlement talents to give full play to the above abilities.

As a professional compulsory course for international trade, financial management and other majors, international settlement has strong operability and practicability. At present, the teaching goal of international settlement course in colleges and universities is to enable students to master the operation skills of international settlement business, be rich in practical ability, innovative spirit and high comprehensive quality, lay a solid foundation for engaging in foreign trade and banking in the future, and cultivate applied talents who meet the market demand. The focus of teaching is to cultivate students' three abilities: first, have knowledge reserve ability to master the professional theoretical knowledge and basic methods of international settlement and be familiar with the of international commercial law and international practices of international settlement; Secondly, have strong professional practice ability, good English ability and strong adaptability; Be able to engage in relevant work flexibly without losing preciseness, openly without losing principle under the framework of international rules; Finally, have high comprehensive quality, including good professional ethics and international business reputation, be able to abide by discipline and law, abide by integrity, and have agile thinking and adaptability. Due to its strong practicability and operability, as well as its close connection with international practices and interdisciplinary characteristics, students feel that the content of the course is boring, numerous and detailed, which is not only difficult to master, but also difficult to generate interest in learning. This leads to a certain difference and distance between the actual teaching effect of the course and the market demand. Therefore, in order to achieve teaching objectives and truly meet the requirements of talent training, teachers need to constantly explore and innovate appropriate teaching models in the teaching process.

\subsection{Main Problems in the Existing Teaching Mode of International Settlement}

At present, the teaching mode of this course in colleges and universities lags behind the actual needs of the society. The course of international settlement is mainly based on the traditional teaching mode of "Teacher centered". Students are only in a passive position. The learning and understanding of knowledge mainly comes from teachers' classroom teaching, which is not conducive to students' mastery of professional knowledge and the cultivation of relevant professional skills. Specifically, the main problems in the existing teaching mode are:

\subsubsection{The Imperfect Teaching Curriculum System Affects the Teaching Quality}

The course of international settlement is comprehensive. The understanding of many concepts and terms in the course of international settlement must rely on the knowledge of some relevant courses. When formulating professional teaching plans, some schools only pay attention to the practical course of international settlement and ignore the relevant courses, or set up the course of international settlement first and then set up the relevant courses. For example, the course of international settlement should be arranged after the course of international trade practice, but the reality is just the opposite, which makes it difficult for students to prepare enough knowledge when learning the course of international settlement. It is precisely because students have insufficient perceptual knowledge of international settlement business and are difficult to grasp the key points. Therefore, it is easy to confuse the concepts and process points in various international settlement business, which has become a difficult point to break through in teaching, thus affecting the teaching quality.

\subsubsection{The Teaching Content is Theoretical and the Teaching Purpose is Not Clear}

International settlement is a multilateral interdisciplinary course, which mainly applies the knowledge of international finance, money and banking, international trade practice, international trade document practice and other related majors. For students have never been involved in specific business operations, theoretical teaching is particularly vague, especially in the introduction of main documents and settlement methods, which is difficult for students to understand and digest. In addition, in order to improve the passing rate of some qualification tests and increase the number of students with certificates, many teachers teach students highly operable subjects in the teaching process of international settlement in the way of examination, ignoring the cultivation of students' actual ability. The teaching objectives and teaching contents deviate from the requirements of the cultivation of applied talents. This leads to the phenomenon that the certified students cannot meet the requirements of the job and need secondary training, which increases the economic cost of the employer and leads to the problem of difficult employment for students.

\subsubsection{The Teaching Mode is Single and the Students' Participation is Not High}

Many undergraduate classroom teaching is the traditional imparting teaching mode, which still takes "teachinglearning-practice" as the basic mode. Teachers are still the main body of teaching. They mainly explain one-way knowledge transmission and students passively and mechanically accept knowledge. Although multimedia assisted teaching is mostly used in the classroom, it does not change the situation of students passively accepting knowledge. Many teachers also try to use diversified teaching methods in teaching, such as case teaching and project teaching, but they still focus on Teachers' teaching and analysis, students' active analysis and participation can not be 
effectively improved, and their learning autonomy can not be brought into play, resulting in poor mastery of professional knowledge, weak ability to analyze and solve problems, let alone innovation and ability training.

\subsubsection{Simulation Practice Teaching is Divorced from Practice}

The course of international settlement is highly practical and operational. Although more and more colleges and universities have set up the practical teaching mode of international settlement, it is mainly software simulation. The content of these software is old, which is different from the actual settlement business operation. The vast majority of colleges and universities still lack comprehensive and designed practical courses. In addition, there are insufficient off campus training bases in colleges and universities, and the effect of students' practical teaching is not obvious. Teachers themselves have not been engaged in the actual business of international settlement. Teachers' lack of practical experience results in simulation practice becoming a mere formality. Students fail to learn how to operate the settlement business and are lack of practical operation ability, which restrict the improvement of the training quality of applied talents.

\subsubsection{The Teaching Process is Less Cutting-Edge and Interactive}

International settlement business is a course that is in line with international practices and constantly keeps pace with the times. In view of the traditional "transmission -acceptance" teaching mode, teachers rarely integrate the most cutting-edge settlement business knowledge to teaching. Students' knowledge can not adapt to the changing needs of the times, and there is less interaction between teachers and students. Therefore, students' self-study ability and innovation ability are weak. These problems lead to students' failure to meet the employment requirements of enterprises and a serious gap between talent supply and demand. And they do not comply with the training objectives of colleges and universities.

\subsection{Method}

\subsubsection{Construction of "TCPP" Teaching Mode of International Settlement Course Under the Training Goal of Applied Talents}

The course of international settlement has the characteristics of practicality, operability and professionalism. In order to achieve the teaching objectives and truly meet the requirements of the training objectives of applied talents, the teaching methods need to be reformed. In view of this, this paper constructs the "TCPP" teaching mode combined with diversified teaching methods to improve students' enthusiasm and interest in learning and their practical business operation ability, so as to improve the teaching effect and cultivate applied international settlement talents.

\section{Results}

3.1. The "TCPP" Teaching Model Consists of Four Links: Theoretical Teaching, Case Teaching, Project Teaching and Practical Teaching. The Construction Diagram of "TCPP" Teaching Mode is as Follows:

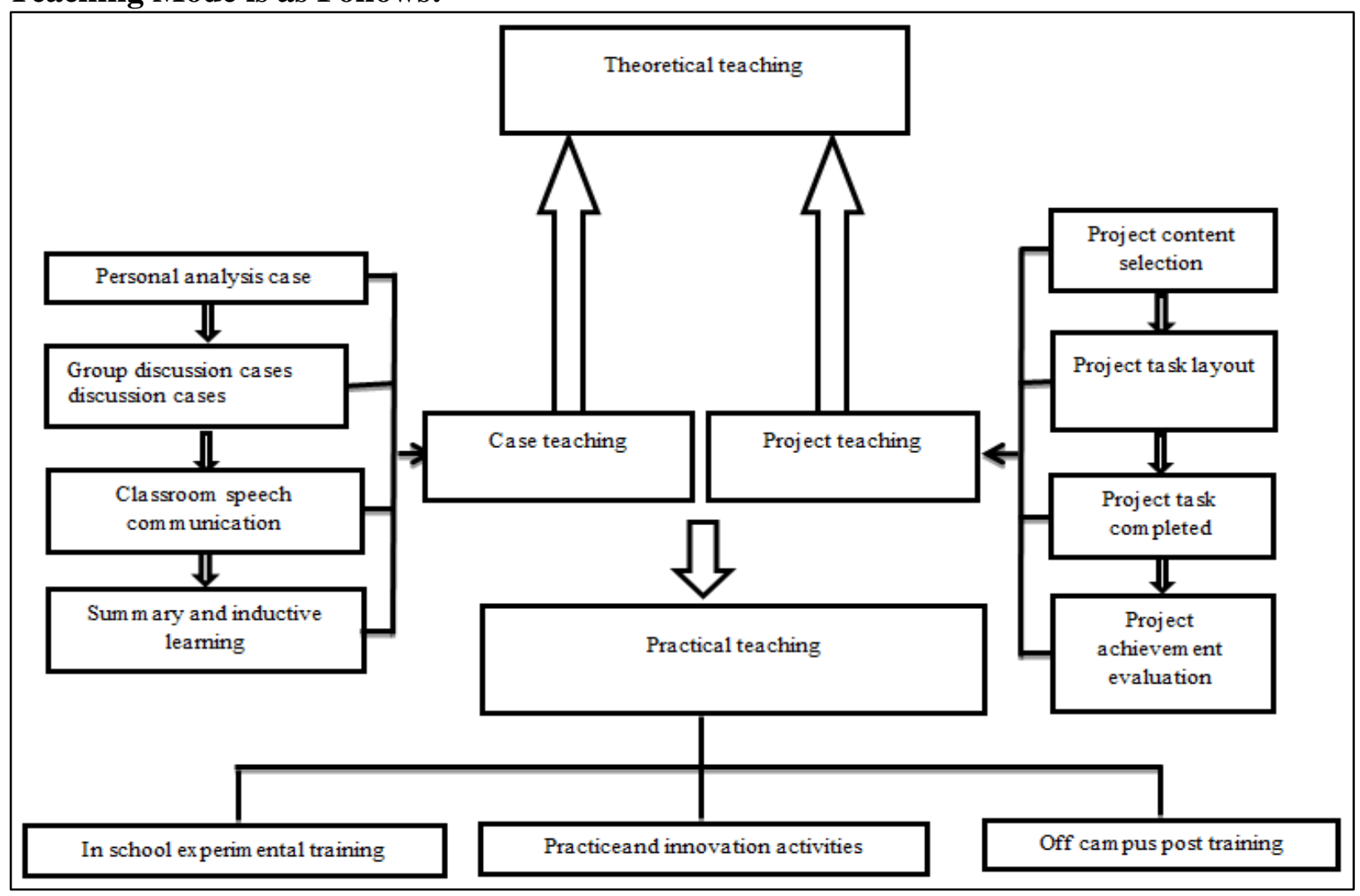




\subsubsection{Theoretical Teaching Links}

Theoretical knowledge serves for post skill training. The essence and key is: what theoretical knowledge to learn depends on what skills training needs. International settlement involves money balance, international capital flow and financial risk prevention in international finance, as well as many related knowledge such as international insurance, transportation, telecommunications, import and export trade, accounting, customs, commodity inspection, bills and law. It is a multilateral interdisciplinary subject based on finance and trade. The course focuses on a number of international practices, rules and legal provisions, and introduces practical practices under the guidance of theory. Therefore, the mastery of theoretical knowledge is the basis of practical business ability. In addition, the teaching content should be combined with the professional qualification training content of posts society needs, so that students can obtain professional qualification certificates more easily before employment, which is conducive to their future employment.

\subsubsection{Case Teaching}

Case teaching means that in the teaching process of international settlement, based on the textbook of international settlement, according to the specific teaching objectives and combined with various actual cases, students can participate in the case discussion activities, so as to improve students' ability to analyze and solve problems, stimulate students' interest in learning and shorten the gap between theory and practice. In case teaching, the relationship between teachers and students is that teachers and students complement each other and teaching complements each other. Case teaching mainly includes four links: reading cases and personal analysis; Group discussion to form consensus; Speak in class and communicate with the whole class; Summarize, digest and improve. In this process, the corresponding teaching methods can be selected according to the difficulty of the case, such as interleaving, problem traction, classroom discussion, heuristic and other specific methods, so as to effectively improve the effect of case teaching.

\subsubsection{Project Teaching Links}

Project teaching is a teaching method in the teaching process, which is practice oriented, teacher led and student-centered. Starting from the actual needs of the profession, it selects typical projects as the teaching content. Guided by these projects, students carry out a series of teaching activities around the projects. The specific application design of project teaching method in the course of international settlement includes four aspects: the selection of project content, the arrangement of project tasks, the completion of project tasks, and the evaluation of project results. The effect of project teaching method depends on many aspects, and puts forward higher requirements for students, teachers and schools. Teachers should first carefully study and analyze the teaching content, pay attention to the students' active thinking, and select the project content on this basis. The design of the project should not only reflect the key and difficult points of the teaching content, but also be vivid and interesting, which can improve students' learning enthusiasm and stimulate students' exploration spirit. Teachers should timely guide students to analyze and discuss the project tasks, help students clarify their ideas, and provide students with relevant clues to solve problems, such as ways to obtain relevant materials and help, ideas to solve problems, etc. When students find answers through their own efforts, teachers should comment and summarize the answers to help students master the key and difficult points of teaching content. Improving their knowledge application ability and adopting project teaching method can better cultivate students' practical operation ability and autonomous learning ability.

\subsubsection{Practical Teaching Links}

Practical teaching is a key link in the cultivation of applied talents. The course of international settlement should make full use of various resources to build a diversified practical teaching platform. The school should establish an experimental teaching platform and add experimental training links. In the school laboratory, students independently complete the relevant experiments of international settlement business, achieve the integration of teaching, learning and doing; teachers help students understand the practical operation process, and solve the difficult problems in theoretical learning in the process of hands-on. The school can establish good school enterprise cooperation relations and sign contracts with some local banks and foreign trade enterprises. The school regularly invites experts or managers from banks and foreign trade enterprises to give special lectures on foreign trade to pass on first-hand foreign trade operation knowledge and skills to students. Students can be arranged to practice in banks or foreign trade enterprises during winter and summer holidays and learn the working process of the business department. In addition, it can extend classroom teaching and improve the scientific research and training platform. According to the course content, teachers arrange research, thesis writing and other training projects, actively guide students to participate in practical innovation activities, and carry out rich and colorful training activities in the form of subject research, social research and discipline competition, so as to improve students' innovation ability and comprehensive quality.

\subsection{Decision}

\subsubsection{Problems Needing Attention in the Application of "TCPP" Teaching Mode of International Settlement Course}

In order to achieve good teaching effect of "TCPP" teaching mode, the following points should be paid attention to in the process of teaching practice: 


\subsubsection{The Teaching Mode is Student-Centered}

In the teaching process, teachers should stimulate students' learning motivation and cultivate students' learning enthusiasm. Each link is mainly completed through students' self-study and practice. Teachers should make full use of the valuable learning resources formed by the differences of existing cognitive structure and individual experience among students, organize students to carry out cooperative learning and share this resource in the teaching process. At the same time, through communication and cooperation, students' individual thinking achievements can be shared by the whole learning group, and reflect on their own and others' views, so as to build a new and deeper understanding. In addition, in the process of cooperation, the cooperative relationship and competitive relationship formed between students not only enhance the team spirit, but also conducive to the survival and development of students' personality.

\subsubsection{Teachers Play an Effective Role in Students' Learning}

First of all, relevant teachers in the teaching and research office must conduct necessary and sufficient research and discussion on the whole teaching design, and prepare lessons collectively. According to the content of each chapter of the course, teachers select classic settlement cases of domestic enterprises that can arouse students' interest, form a case base, and prepare various learning tools, such as textbooks, teaching reference materials, networks, etc; Secondly, the content of each teaching link should be fully integrated with practice. Teachers shouldn't only provide students with pure theoretical knowledge divorced from real life, but must aim to solve the problems actually encountered by enterprises in the real environment. Teaching should be based on students' existing knowledge and life reality. Teachers should help students learn the settlement in life and the settlement useful for future work, provide students with opportunities for self-expression and exercise, let students truly experience the settlement, enable students to experience the joy of success, learn from failure, summarize experience, and enhance their consciousness and initiative in learning; Finally, teachers should fully respect students' different ideas, views and practices in the teaching process, encourage students to boldly try and make decisions according to their own views, and let students have a deeper understanding and experience of their own decisions through the simulated results, and adjust their own cognitive structure.

\subsubsection{Teachers Should Adopt Diversified Teaching Methods When Teaching}

In each teaching link, teachers should adopt a variety of different teaching methods to achieve the final teaching goal, such as inquiry teaching, task-driven teaching, teaching method, experimental teaching, scene simulation teaching, bilingual teaching, multi-layer interactive teaching or the latest micro class, Mu class, flipped class and so on.

\subsubsection{Teachers Should Change the Traditional Assessment Methods in the Teaching Process}

Setting a reasonable assessment method will certainly play a good role in guiding and encouraging the learning of the course. The assessment shall include theoretical assessment and practical assessment. Teachers should reasonably allocate the proportion of theoretical assessment and practical assessment. The assessment of theoretical part can adopt the usual phased test, that is, students can be evaluated and assessed by stages in the learning process. Their usual performance and homework will be used as the basis for assessment. Teachers will not determine the score based on a final paper so as to avoid students paying no attention to lectures during class and memorizing by rote before the exam. In this way teachers change the "one-time exam" into "incentive" exam and give effective play to students' subjective initiative. In practical assessment, oral examination can be taken to assess the effect of case teaching and exercise their cooperative spirit; For the simulated practice teaching content, computer operation can be taken to assess students' creativity and practical ability, gradually increase students' self-regulation of learning activities, and make them truly realize that they are the main body of learning.

\section{Discussion}

\subsection{Main Problems to be Solved}

The research of this project is forward-looking, and the research problems have a certain depth and difficulty. Through the research of this project, the following problems are expected to be solved:

The talents trained by the traditional teaching mode of international settlement are out of touch with the employment needs of enterprises. Graduates trained under the traditional teaching mode are not competent for the job requirements of enterprises. Foreign trade enterprises and banks are unwilling to accept such students, resulting in the situation that students learn but are useless.

There is no innovation in the teaching mode of international settlement, and there are too many forms in the teaching. "TCPP" teaching mode can better complete the tutorial teaching tasks, especially pay attention to the cultivation of students' ability, which is conducive to the cultivation of innovative compound talents and better complete the "zero" distance docking with enterprises.

It is conducive to the significant improvement of the teaching effect of international settlement. Teachers' leading role and students' dominant position are fully respected, and students' enthusiasm, creativity and interaction are brought into full play in the teaching process. 


\subsection{Research Objectives}

This paper intends to attract the attention of training units in Colleges and universities through public publication, so as to achieve the following research objectives:

\subsubsection{Theoretical Objectives}

Based on the investigation of universities and employers, this paper systematically puts forward the problems existing in the teaching process of international settlement in Colleges and universities, and constructs the "TCPP" teaching mode of international settlement under the training goal of applied talents. This research achievement will fill the deficiencies in the reform and practical research of the curriculum system of international settlement in Colleges and universities, and enrich the diversification of teaching modes and methods of international settlement.

\subsubsection{Application Target}

This research will mainly build the "TCPP" teaching mode to realize the combination of teaching and research, in class and out of class, common training and personality development, dynamic and static, effectively enhance students' learning interest, and achieve the training goal of students' knowledge, ability and comprehensive skills. As an effective teaching mode, "TCPP" teaching mode is conducive to enhance students' learning interest and cultivate students' professional ability.

The realization of this research is conducive to the innovation of specific teaching methods in curriculum teaching, the use of various teaching methods, the completion of curriculum teaching tasks and the cultivation of applied innovative talents. Demonstrate the teaching reform effect of international settlement course in our university and other universities, so as to improve the teaching effect of international settlement course in our university. So as to promote the in-depth development of the teaching reform of international settlement, improve the teaching effect of international settlement, and promote the connection between school talent training and enterprise talent demand.

\section{Conclusions}

To sum up, the talents trained by the traditional teaching mode of international settlement are out of touch with the employment needs of enterprises. Graduates trained under the traditional teaching mode are not competent for the job requirements of enterprises. Foreign trade enterprises and banks are unwilling to accept such students, resulting in the situation that students learn but are useless. The "TCPP" teaching mode based on the actual needs of employers can better complete the course teaching tasks, especially pay attention to the cultivation of students' ability, fully respect students' main position, give full play to students' enthusiasm, creativity and interaction, and significantly improve the teaching effect of international settlement, better promote the "zero" distance connection between the training of Applied Talents in schools and the talent needs of enterprises.

\section{Acknowledgment}

We thank the anonymous reviewers and editors for their very constructive comments. This work was supported by the first batch of industry university cooperation collaborative education projects of the Ministry of Education under Grant 202101217010 and the teaching research project of Anhui University of Finance \& Economics of China under Grant acszjyyb2021054 and the science research project of Anhui University of Finance \& Economics of China under Grant ACKYC21032.

\section{References}

Meng Liang (2021). Research on the teaching reform of "PBL+semi flipped classroom" for economics and Management Majors-Taking the course of international settlement as an example. University Education, 6(10): $148-50$.

Wang $\mathrm{Na}$ (2019). On the teaching reform of international settlement course based on the cultivation of applied talents. Chinese Journal of Multimedia and Network Teaching, 9(10): 52-55.

Wang Xiaodong (2013). Research on the path of constructing modern international settlement comprehensive training room in higher vocational colleges. Laboratory Research and Exploration, 3(6): 235-38.

Xiao Jing (2020). Curriculum reform and practice of international settlement based on OBE model. Science and Technology Wind, 7(10): 98-100. 